\title{
Availability of Ground-Water Data for Washington, 2004
}

\begin{abstract}
The U.S. Geological Survey has been investigating groundwater resources in the State of Washington since the early part of the 20th century. During this time, the use of ground water evolved from meager domestic and stock needs to complex requirements for public-water supplies, large irrigation projects, industrial plants, and numerous other uses. Groundwater data are of considerable importance in making resourcemanagement decisions including determining water availability, allocating water permits, and locating sources of pollution.
\end{abstract}

\section{National Water Information System}

Ground-water data collected by the U.S. Geological Survey (USGS) are entered into the USGS National Water Information System (NWIS) (U.S. Geological Survey, 1998). The National Water Information System Web System (NWISWeb) web site, http://waterdata. usgs.gov/nwis/, provides public access to several million items of historical and real-time data (U.S. Geological Survey, 2002).

Ground-water data are published by the USGS in various data and investigative reports. A list of these reports is available at the USGS Washington Water Science Center's web sites http://wa.water.usgs.gov/ data/gw/ and http://wa.water.usgs. gov/pubs/.

\section{Ground-Water Database for Washington}

The Ground-Water Database for Washington provides online access to the following ground-water data:

- Site information

- Ground-water levels

- Real-time data

- Water-quality data

The database is a combination of data collected by the USGS and by many other Federal, State, and local agencies; tribal nations; and numerous private and public organizations. The database does not include all the ground-water data for Washington.

\section{Site Information}

As of June 1, 2004, the Ground-Water Database for Washington contained descriptive-site-information for 85,922 ground-water sites in the State. Of these sites, 84,940 are wells or test holes; 842 are springs or seeps; and 140 are drains, excavations, or other types of groundwater sites.

Descriptive-site-information can be accessed at the USGS Washington Water Science Center's web site, http://waterdata.usgs.gov/ wa/nwis/gwsi.

\begin{abstract}
Ground-Water Levels and Real-Time Data
The Ground-Water Database for Washington (as of June 1, 2004) contained 222,035 discrete water-level measurements for 72,417 ground-water sites in the State. The database also contained data for one real-time groundwater site in Washington.
\end{abstract}

Discrete depth-to-water data can be accessed at the USGS Washington Water Science Center's web site, http://nwis.waterdata.usgs.gov/wa/ nwis/gwlevels, and hydrographs of the data can be accessed at http://wa.water.usgs.gov/data/gw/ Iterm.htm.

Real-time data can be accessed at the USGS Washington Water Science Center's web site, http://wa.water.usgs.gov/data/gw/rtime.htm, and hydrographs of the data can be accessed at http:// waterdata.usgs.gov/wa/nwis/current.

\section{Water-Quality Data}

The Water-Quality Database for Washington contained data and information on the chemical, physical, and biological properties of ground water from 9,336 ground-water sites in the State (as of June 1, 2004).

Water-quality data can be accessed at the USGS Washington Water Science Center's web site, http://waterdata.usgs.gov/wa/nwis/qw.

\section{Structure and Types of Data in the Ground-Water Database for Washington}

\section{Site Information}

Descriptive site information including latitude, longitude, well depth, and site use.
Ground-Water Levels

Depth to water or watersurface elevation in wells.

\section{Real-Time Data}

Data transmitted from

selected ground-water sites.

\section{Water-Quality Data}

Chemical, physical, and biological properties of ground water. 


\section{Site Identification}

Each site in the Ground-Water Database for Washington is assigned a unique site number and a unique site name. The site number is a 15 -digit number formed from the initial latitude and longitude of the site in degrees, minutes, and seconds, and a 2-digit sequence number. For example, the first 6 digits of the site number are the latitude, the 7 th through 13th digits are the longitude, and the 14th and 15th digits are sequence numbers used to distinguish between sites at the same location. Leading zeros are used as needed so the site number will not contain blank spaces. Although the site number is based on the initial latitude and longitude of the site, once assigned the number is used only as an identification number; it has no location significance and cannot be changed.
The site name for a ground-water site in Washington is based on the site's location in terms of the Public Land Survey rectangular grid system (fig. 1). For example, in site name 25N/45E$11 \mathrm{~K} 01,25 \mathrm{~N}$ indicates the township north of the Willamette base line; 45E indicates the range east of the Willamette meridian; 11 indicates the section; and $\mathrm{K}$ indicates the 40 -acre tract (quarter-quarter) within the section. The number following the section (01) is a sequence number that indicates the order in which wells in the same quarter-quarter were identified for entry into the database. A suffix after the sequence number indicates that a well has been deepened (D1) or reconditioned (R1) after its initial construction. The suffix $\mathrm{S}$ identifies a site as a spring rather than a well.
Although many agencies and organizations in Washington use similar numbering and naming systems, consistency of assigned site numbers and names between agencies should not be assumed.

\section{References Cited}

U.S. Geological Survey, 1998, National water information system (NWIS): U.S. Geological Survey Fact Sheet 027-98, 2 p.

U.S. Geological Survey, 2002, NWISWeb: New site for the nation's water data: U.S. Geological Survey Fact Sheet 128-02, 2 p.

\section{For more information contact}

Ron Lane at rclane@usgs.gov, (253) 428-3600 ext. 2604, or

Luis Fuste' at lafuste@usgs.gov, (253) 428-3600 ext 2653.

Washington Water Science Center U.S. Geological Survey 1201 Pacific Avenue, Suite 600 Tacoma, Washington 98402 http://wa.water.usgs.gov/ \begin{tabular}{l|r|r|r|r|r|r|}
\hline & \multicolumn{1}{|c|}{7} & 8 & 9 & 10 & $11^{\bullet}$ & 12 \\
\hline \multirow{2}{*}{25} & 18 & 17 & 16 & 15 & 14 & 13 \\
\hline 19 & 20 & 21 & 22 & 23 & 24 \\
N. & 30 & 29 & 28 & 27 & 26 & 25 \\
\hline 31 & 32 & 33 & 34 & 35 & 36 \\
\hline
\end{tabular}

25

\begin{tabular}{l|r|r|r|r|r|r|}
\cline { 2 - 7 } T. & 7 & 8 & 9 & 10 & $11^{\bullet}$ & 12 \\
\hline \multirow{2}{*}{25} & 18 & 17 & 16 & 15 & 14 & 13 \\
\hline & 19 & 20 & 21 & 22 & 23 & 24 \\
\hline N. & 30 & 29 & 28 & 27 & 26 & 25 \\
\hline 31 & 32 & 33 & 34 & 35 & 36 \\
\hline
\end{tabular}
R. $45 \mathrm{E}$
W A S H I N G T O N

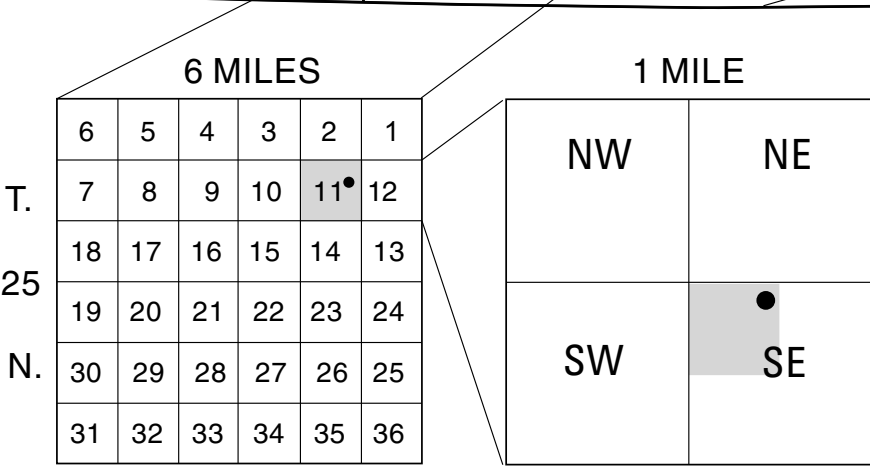

SECTION 12

474033117044001

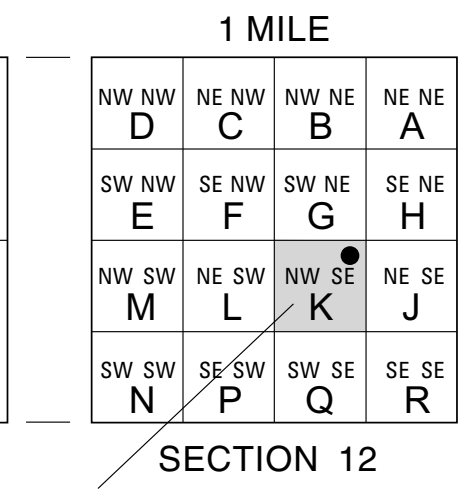

$25 N / 45 E-11 K 01$

Figure 1. Ground-water site naming system used in Washington. 